IBT Journal of Business Studies

Volume 14(2), 209-220, 2018

\title{
Multi-Dimensional Effect of Oil Pricing On Pakistan Economy: A Case of Study
}

\author{
Qamar Ul Arafeen ${ }^{l}$ \\ S.M Ahsan Rizvi ${ }^{2}$ \\ Muhammad Imran Hanif \\ Syed Nayyar Ali ${ }^{4}$
}

\begin{abstract}
Pakistan economy is growing steadily. This growth demands higher energy consumption and consequently putting high pressure on countries economy. Pakistan mainly depends upon oil and gas resources to fulfill energy requirements. Indigenous resources of Oil are not enough to quench energy thirst of the growing economy. As a result Pakistan has to import large quantity of oil and oil based products from Middle East countries. Gas reserves in the country are enough for current gas requirements. So natural gas is playing a key role in power sector. Currently in oil upstream and doswnstream sector there are some local and international companies involved and government of Pakistan is establishing such policies that it can attract more international investors in this sector but the rapid pace of change, high degree of uncertainty and unstable political situation of the country present significant challenges and risk to foreign investment.

The paper is a review of possible consequences and challenges presented by high oil prices in Pakistan. Pakistan is heavily dependent on imported fuels and this dependence is expected to increase even further in future given the depleting gas resources. The rising oil prices in the international market has had affected negatively balance of payment position as well as on the budgetary position of the country and contributed in creating inflationary pressures in the economy. For long run development oil will remain an important source of energy. The government should chalk out strategies for ensuring efficiency in use; and development, adequacy and reliability of supply and the pricing of petroleum products in such a way that will not create extra burden on the consumers. Unless appropriate steps are taken this trend of rising oil prices will further aggravate the negative impacts on the economy.
\end{abstract}

KEY WORDS: Import Parity Price (IPP), Light Diesel Oil (LDO), Motor Spirit (MS), High Speed Diesel (HSD), Oil Marketing Companies (OMCs), Import Parity Price (IPP), Oil Companies Advisory Committee (OCAC), Oil and Gas Regulatory Authority (OGRA)

\footnotetext{
1- ILMAUniversity, Karachi, Pakistan,drlodhi@gmail.com

2- Associate Professor, Management Science Department, Bahira University, Karachi, Pakistan, ahsanrizvi.bukc@bahria.edu.pk

3- Institute of banking \& finance, Bahauddin Zakria University, Multan, Pakistan, mimrahanif@bzu.edu.pk

4- General Studies Department, Yanbu Industrial College, Madinat, Saudi Arabia.
} 


\section{INTRODUCTION}

The research incorporates the effect of global crude oil prices on domestic oil products from the year 2005-2008. An oil-price increase leads to a transfer of income from importing to exporting countries through a shift in the terms of trade (Ahmed, A., and M. J. Kumar (2008). The magnitude of the direct effect of a given price increase depends on the share of the cost of oil in national income, the degree of dependence on imported oil and the ability of end-users to reduce their consumption and switch away from oil. Naturally, the bigger the oil-price increase and the longer higher prices are sustained, the bigger the macroeconomic impact. For net oil-exporting countries, a price increase directly increases real national income through higher export earnings (Akram, M., (2012).

Higher oil prices lead to inflation increased input costs, reduced non-oil demand and lower investment in net oil importing countries. Tax revenues fall and the budget deficit increases, due to rigidities in government expenditure, which drives interest rates up. An oil-price increase also changes the balance of trade between countries and exchange rates. Net oil-importing countries normally experience decline in their balance of payments, putting downward pressure on exchange rates (Chuku, A. C., E. L. Effiong and N. R. Sam (2010). As a result, imports become more expensive and exports less valuable, leading to a drop in real national income. Considering the impact of oil imports on the importing countries stated with a birds eye view in the above paragraphs and knowing that Pakistan is an oil importing country, I have selected this topic to identify and study how the changes in the prices of crude oil in the world market affect our domestic oil products prices and how domestic oil pricing affect economy.

\section{LITERATURE REVIEW}

(Muhammad, 2013), describe that oil price shock have a significance impact on economic growth and rising prices have different impact on oil importer and exporter countries while public or private sector investment enhanced the GDP rate of the economy.

(Nadia, 2013), explained that oil was most important factor which affects country economy directly. They concluded that Pakistan is an oil importer country and paying its financial reserve to fulfill the oil market requirement which badly affect the stock exchange market of the country.

The price of crude oil is among the most important prices quoted daily across the world which is not surprising, since crude oil is the most widely used source of energy worldwide. In the petroleum industry's 160-year history, three eras of rise in oil prices have been observed. In all these time prices have plummeted and spiked due to various reasons (Colongni, A. and M. Manera (2008). When petroleum burst onto the world stage in 1859, its price first went through some initial gyrations before settling in the \$1.00-2.00 per barrel range for a full century. The first period lasted from 1860 until about 1970. It was called the "Era of growing surpluses". During this time, the key events in oil pricing had mostly to do with new discoveries and other events that increased production. There was a general decline in real oil prices, because the amount of oil available was steadily increasing (Abeysinghe, Tilak (2001). The second era, the "Era of energy price shocks" lasted from 1973 until almost 2000. Three price shocks - each a combination of geopolitical events and market forces - helped drive oil prices. The first two shocks were the price spikes of 1973 and 1979-80, which were responses to events in the Middle East and OPEC's control of supplies. Then market forces, less demand from the world's consumers combined with increasing production, especially from OPEC producers led to the third shock in 1986 resulting in rapid collapse of oil prices. Thereafter, the price entered the relative stability of the $\$ 15-20$ per barrel.

The third period began a decade ago; we can call it the "Era of tighter supply". Virtually all observers agree that prices have been steadily rising because oil supplies are "tight" - that is, there is little surplus oil supply to compete for existing demand. Much of the reason for this strong demand is the

Page $\mid 210$ 
powerful global economy, which demands ever-greater supplies of oil. In short, geopolitical events and concern about the availability of oil supplies are having strong impacts on crude oil prices. Many factors are now in play. These include war, terror and political instability; industrial incidents like plant and pipeline failure; storms and abnormally high and low temperatures; rapid economic growth in the developing world; industry reports and financial news and rumors, especially as they apply to oil demand and supply. During the era of tighter supply, these factors can be powerful short-term forces driving changes in crude oil prices. Rarely before has this been the case, and never before could seemingly small incidents trigger such large price movements. Today world oil prices are hovering around $\$ 65$ bbl. World oil demand is increasing with agricultural, transport, and power plant fuels seeing the highest consumption. The demand is growing the most in the USA, China, the Middle East, and other Asian countries, especially India. World oil demand for the third quarter of 2008 is forecast to grow by $1.5 \mathrm{mbbl} /$ day to an average of $85.7 \mathrm{mbbl} /$ day. In 2009 , world oil demand is forecast to grow by $1.3 \mathrm{mbbl} /$ day to an average of $87.1 \mathrm{mbbl} /$ day.

The oil and gas sector has a considerable impact on the economy - the sector attracts by far the highest level of foreign direct investments in the country (Cunado, J. and Perez de Gracia (2005). The majority of produced oil comes from proven reserves located in the southern half of the country, with the three largest oil-producing fields located in the Southern Indus Basin. Additional producing fields are located in the Middle and Upper Indus Basins. Pakistan has an interesting Geo-dynamic history of large and prospective basin with sedimentary area of 827,268 sq km. So far about 935.869 million barrels crude oil reserves have been discovered of which 609.191 million barrels have already been produced. To date 716 exploratory wells have been drilled by various national and international exploration and production companies, resulting in over 2017 oil and gas discoveries.

The government also changed the guaranteed return formula of the refineries to an Import Parity Price (IPP) formula. Previously, the refineries were working under a fixed return formula where the return was capped in the range of $10-40 \%$ of their equity. Thus, government was liable to meet any loss in the profitability of the refineries. Under the new formula, an import tariff is applied to the FOB price of the petroleum product to determine the ex-refinery prices. The import protection is essentially the margins of the refineries. Here it would be useful to add that the bulk of the crude oil requirement of Pakistan refineries is met through government to government contracts with Saudi Arabia. The terms of these contracts are not made public and refineries are charged market (international) related prices, any benefit or discount goes to the government. Domestic crude is supplied to the refineries at prices consistent with the policy applicable at the time the concession was awarded. In 2001, the government authorized the Oil Companies Advisory Committee (OCAC) to review, fix and announce the prices of petroleum products on fortnightly basis in accordance with the approved pricing formula with effect from July 1, 2001 as a part of deregulation policy. Therefore, between July 1, 2001 and April 1, 2006, OCAC reviewed and announced the ex-depot prices of motor spirit (gasoline), kerosene, and light diesel oil fortnightly in accordance with the approved formula (Table 1). Later on, the function of price fixation was transferred to Oil and Gas Regulatory Authority (OGRA). Since April 16, 2006 OGRA is responsible for price notification. 
Table No.1 Import Parity Pricing (IPP) mechanism

\begin{tabular}{|c|c|}
\hline \multicolumn{2}{|c|}{$\begin{array}{c}\text { Ex-Depot Sales Price }=\text { Ex-Refinery Price }+ \text { Inland Freight Equalization Margin }(\text { IFEM) }+ \text { OMC Margin }+ \\
\text { Distribution Margin }+ \text { Petroleum Development Levy }(\text { PDL) }- \text { Petroleum Development Claims (PDC) + General } \\
\text { Sales Tax }\end{array}$} \\
\hline \multicolumn{2}{|r|}{ Description } \\
\hline Ex-Depot Sales Price & It is the price at which POL products are sold on the stations \\
\hline Ex-Refinery Price & It is the price at which OMCs get POL products from the refineries \\
\hline $\begin{array}{l}\text { Inland Freight Equalization } \\
\text { margin (IFEM) }\end{array}$ & $\begin{array}{l}\text { This number is determined by OCAC in order to set uniform prices of } \\
\text { petroleum products all across the nation }\end{array}$ \\
\hline OMC Margin & $\begin{array}{l}\text { The amount per litre that OMCs get as their margin. (Previously it was } \\
3.5 \% \text { but nowadays it is capped at the level of USD100 per barrel) }\end{array}$ \\
\hline Distribution Margin & $\begin{array}{l}\text { The amount per litre that distributors get as their margin. (Previously it was } \\
4.0 \% \text { but nowadays it is capped at the level of USD100 per barrel) }\end{array}$ \\
\hline Petroleum Dev. Levy (PDL) & A tax charged by the government (Inflow for government) \\
\hline Petroleum Dev. Claims (PDC) & A subsidy given by the government (Outflow for government) \\
\hline General Sales Tax (GST) & A tax charged by the government @ $16 \%$ (Inflow for government) \\
\hline
\end{tabular}

\section{Source: Oil and Gas Regulatory Authority (OGRA)}

In the pricing formula, ex-refinery price (or import parity price (IPP)) are determined on the basis of average fortnightly prices of petroleum products in international market (Arab Gulf market). Other components are customs and excise duty, petroleum development levy (PDL), distribution margin for oil marketing companies (currently $3.5 \%$ of ex-depot sale price), dealer's commission (4\%) and a $15 \%$ sales tax. Most components of the end user price, other than IPP are relatively stable, although the government has often adjusted PDL in an ad-hoc fashion to keep the final price constant.

Government decides to increase, decrease or maintain the consumer prices by making adjustments in PDL through its notifications issued under Petroleum Products (Petroleum Development Levy) Ordinance, 1961 (XXV of 1961). Government advises PDL on fortnightly basis to OGRA.

\section{Relationship between Oil Prices and Economic Growth in Pakistan}

After a long declining period of Pakistan's economic growth, in current fiscal year economic growth has been increased. This growth positive factor has been came in the development in industrial, agricultural sector of the economy and government also making focus to enhance the productivity level from 395 billion which was 326 billion in last year only. Gross domestic product (GDP) of Pakistan also accelerates above to $4 \%$ which was below the $3 \%$ in last year. 


\section{Research Statement}

The research statement of my report is:

\section{"Oil Pricing and its Impact on Pakistan Economy"}

- The report focus on the following areas:

- Oil scenario in Pakistan, its production, consumption and import.

- Refineries refining capacity and their production.

- Fluctuation in Global oil prices from 2001-2007.

- Role of OGDC in regulating and setting oil prices in Pakistan.

- Impact of oil prices on local oil products such as Furnace oil, Motor Spirit, HOBC, HSD, LDO, Kerosene Oil.

Keeping in mind the above research statement, I have developed the following hypothesis:

Null Hypothesis:

\section{$\mathrm{H}_{0}$ : "Hike in oil prices will have a negative impact on Pakistan economy"}

Alternate Hypothesis:

$\mathrm{H}_{1}$ :"Hike in oil prices will not have a negative impact on Pakistan economy"

A hypothesis is an unproven proposition or supposition that tentatively explains certain facts or phenomena. It is a statement, an assumption. In its simplest from a hypothesis is a guess. The null hypothesis is a statement about a status quo. An alternative hypothesis is a statement signifying the opposite of the null hypothesis. The hypothesis will be supported by the information gathered from the primary and secondary data as well as on the knowledge and understanding of the researchers. The acceptance of null hypothesis will automatically reject the alternative hypothesis and vice versa.

\section{Significance}

Oil is one of the major energy sources for the developed and developing countries of the world. Since it is a finite source of energy, the oil producing countries are worried about the future of oil demand and supply.

This research study will help me in understanding the oil prices mechanism and how the fluctuations in these prices affect the domestic oil products and the economy in my research study. The oil products of my research are Furnace Oil, Motor Spirit, HOBC, HSD, Kerosene Oil, LDO and Aviation Fuel. The Government of Pakistan is very much aware of increasing oil demand and is ceiling the price of petroleum products to reduce additional cost of POL being passed on to consumers and businesses.

\section{Scope}

This research study is based on the Pricing of oil products and its impact on Pakistan economy for the year 2005-2008. From the domestic perspective, the report focuses exclusively on the domestic crude oil prices. The role of Oil and Gas Regulating Authority (OGRA) in setting oil prices is studied. The data, statistics, tables, figures, charts and other pictorials included in the report will be from the time span stated above. The information gathered from primary and secondary data sources is used to test the Null and Alternate Hypothesis. The acceptance of null hypothesis will nullify the alternative hypothesis and vice versa.

\section{Delimitations}

During the course of my research the following delimitations were faced. 
- Non availability of primary data.

- Uncertainty in world oil prices. The price of crude oil changed dramatically from $\$ 148$ $\mathrm{bbl} /$ day to $\$ 36 \mathrm{bbl} /$ day.

- Uncertainty in domestic oil prices.

- Once Global Oil prices are set than how domestic oil prices are determined.

\section{RESEARCH METHODOLOGY}

\section{Research Design}

This research study is causal in nature. A causal research is one which identifies cause-and-effect relationships among variables. In other words a change in one factor is the means for producing another event. In causal studies it is typical to have an expectation of the relationship to be explained, such as the influence of price, packaging, advertising on sales.

Causal research attempts to establish that when we do one thing, another thing will follow. In causal research having an appropriate causal order of events or sequence is one criterion that must be met to establish a causal relationship. For instance, the change in global crude oil prices is one factor or cause which produces a chain of events or effects in domestic oil prices as well as the economy of Pakistan.

\section{Respondents of the study}

As crude oil prices are an important issue for industrialists, transporters and traders alike, it will be an enormous source of information for all of them. The report will be mailed to the interviewees of my sample. Therefore, it will acquaint them with vital information and key statistics.

\section{Instruments used in the study}

The nature of my research study requires me to collect both primary data as well as secondary data. Also to qualify in establishing causal relationship in my research, I need to incorporate the qualitative and quantitative data too. The quantitative data is one which is stated in numbers; percentages while qualitative data is not in numbers but words, observations and other expressive descriptions.

The source of primary data is personal interviews. For these interviews self administered questionnaires are designed with open ended questions to elicit the pertinent information.

\section{Sampling Frame}

The sampling frame is a list of elements from which a sample is drawn. For my research the sampling frame is as follows:

- Oil Refineries in Pakistan

- Oil Marketing Companies (OMC's) in Pakistan

- Out of these two the sampling unit is chosen. The sampling unit is the number of units chosen as a sample from the sampling frame. The sampling units are:

- Pakistan Petroleum Limited

- Oil \& Gas Development Company

- Pakistan State Oil (PSO)

- Shell Pakistan

- Caltex Chevron Pakistan 
Interviews are conducted with in these organizations to collect primary data

\section{Data Analysis}

Analysis is the application of reasoning to comprehend and interpret the data that has been gathered. Undoubtedly, it is the most important phase of the research and provides foundation for the current and future decision making.

As primary and secondary data is both qualitative and quantitative in nature, the quantitative data is analyzed by using different statistical presentation tools such as:

$\begin{array}{ll}- & \text { Line graphs } \\ - & \text { Bar charts } \\ \text { - } & \text { Pie charts and } \\ \text { Percentages }\end{array}$

The quantitative data is arranged in tables also. To prove the hypothesis' I have used mathematical calculations. Since the Population (total number of refineries and OMC's operating in the Pakistan are only seven and six respectively) and sampling units are almost the same statistical tools cannot be employed in hypothesis testing. The methods used in test of hypothesis are designed by researchers' knowledge and understanding. On the whole data analysis is performed on the basis of interviewees' views, secondary data, and researchers' comprehension on the subject.

\section{Presentation Analysis}

\section{Hypothesis}

The following hypothesis were developed in our research study

Null Hypothesis:

$H_{0}$ : "Hike in oil prices will have a negative impact on Pakistan economy"

Alternative Hypothesis:

$H_{l}:$ "Hike in oil prices will not have a negative impact on Pakistan economy"

Three methods are used to prove the alternative hypothesis.

\section{Hypothesis Testing}

\section{Method 1. Energy Supply Mix}

Pakistan's energy mix is dominated by oil and gas. Together they contribute $79 \%$ of the total primary energy supplies of the country. Out of a total of 62.9 million tones energy of oil equivalent commercial primary energy used by the country during 2007-08 was Natural Gas contributed $47.50 \%$, Oil $30.50 \%$, Hydroelectricity $11.0 \%$, Coal $9.20 \%$, Nuclear $1.2 \%$ and LPG $0.7 \%$.

\section{Energy Supply Mix of Pakistan 2008}

To date, the country has not been able to meet its oil demand. The total refining capacity is just 263,000 $\mathrm{bbl} / \mathrm{d}$, whereas the consumption has reached $370,000 \mathrm{bbl} / \mathrm{d}$. Pakistan has to import almost $80 \%$ of oil from oil rich countries particularly Saudi Arabia and Kuwait. The refining capacity is not enough to meet the demand and so almost all OMC's need to import petroleum products from abroad (Langdon, D. Clough 2007). Shell Pakistan is one such OMC that imports refined petroleum products. PSO which is the largest OMC in the country with a market share of $65 \%$ is also involved in importing oil and petroleum products besides storage and distribution facilities. 


\section{Oil and Gas Energy Sector 2008}

The (Table 2) shows the projected energy demand which includes the demand of oil increasing from 16 MTOE in FY2006 to 31 MTOE in FY2015. The table shows the projected indigenous energy supply and deficit. The figures indicate that oil supply will decline over time (Pakistan Energy Yearbook (2008). The reasons would be; depletion of oil reserves, lower investments in oil exploration and production projects, lack of technological equipment's for exploration and production, inefficiency in oil refining capacity, economic conditions.

Table 2. Projected Energy Demand 2006-2025

\begin{tabular}{|l|r|r|r|r|r|r|}
\hline & \multicolumn{1}{|c|}{ FY06 } & \multicolumn{1}{c|}{ FY15 } & \multicolumn{1}{c|}{ FY25 } & \multicolumn{1}{c|}{ FY06 } & \multicolumn{1}{c|}{ FY15 } & \multicolumn{1}{c|}{ FY25 } \\
\hline & Million TOE & Million TOE & Million TOE & Share in \% & Share in \% & Share in \% \\
\hline Sources & & & & & & \\
\hline Oil & 16 & 31 & 53 & 28 & 27 & 25 \\
\hline Gas & 29 & 57 & 99 & 50 & 50 & 47 \\
\hline Coal & 4 & 9 & 17 & 7 & 8 & 8 \\
\hline Hydel & 7 & 13 & 29 & 12 & 11 & 14 \\
\hline Renewable & - & 1 & 5 & 0 & 1 & 2 \\
\hline Nuclear & 1 & 2 & 8 & 2 & 2 & 4 \\
\hline Total & 58 & 114 & 211 & 100 & 100 & 100 \\
\hline
\end{tabular}

The projected figures show that by 2015 Pakistan's oil demand will be 31 MTOE whereas the supply will only be 3 MTOE. Further down the road the supply will decline to 2 MTOE in 2025 as shown in (Table 3) while the demand will be 53 MTOE. The oil demand and supply from FY2006 to FY2025 projected by Pakistan's Ministry of Petroleum and Natural Resources shows the demand of crude oil will outpace its supply.

Table 3. Projected Indigenous Energy Supply and Deficit 2006-2025

\begin{tabular}{|l|r|r|r|}
\hline & \multicolumn{1}{|c|}{ FY06 } & \multicolumn{1}{c|}{ FY15 } & \multicolumn{1}{c|}{ FY25 } \\
\hline & \multicolumn{1}{|c|}{ Million TOE } & \multicolumn{1}{c|}{ Million TOE } & Million TOE \\
\hline Sources & 3 & & 2 \\
\hline Oil & 29 & 4 & 19 \\
\hline Gas & 2 & 34 & 13 \\
\hline Coal & 7 & 5 & 29 \\
\hline Hydel & 1 & 3 & 12 \\
\hline Renewable and Nuclear & 14 & 61 & 75 \\
\hline Total Indigenous Supply & 58 & 114 & 211 \\
\hline Total Energy Requirement & 17 & 53 & 136 \\
\hline Deficit & $29 \%$ & $46 \%$ & $64 \%$ \\
\hline Deficit as \% of Energy Requirement & & & \\
\hline
\end{tabular}

\section{Method 2.Oil Refining Capacity of the Samples}

The refining capacity of three refineries in our sample is as follows:

\section{Refineries}

Pak Arab Refinery

Pakistan Refinery limited

National Refinery Limited

Dhodak Refinery

Attock Refinery

Bosicor Refinery

ENAR Refiner

Total refining capacity

Total consumption of crude oil Deficit

\section{Refining Capacity}

$91900 \mathrm{bbl} / \mathrm{d}$

$42886 \mathrm{bbl} / \mathrm{d}$

$55344 \mathrm{bbl} / \mathrm{d}$

$2450 \mathrm{bbl} / \mathrm{d}$

$40000 \mathrm{bbl} / \mathrm{d}$

$30632 \mathrm{bbl} / \mathrm{d}$

$2250 \mathrm{bbl} / \mathrm{d}$

$295462 \mathrm{bbl} / \mathrm{d}$

$(378,000) \mathrm{bbl} / \mathrm{d}$

$(82538) \mathrm{bbl} / \mathrm{d}$
Production

$76291 \mathrm{bbl} / \mathrm{d}$

$44150 \mathrm{bbl} / \mathrm{d}$

$52960 \mathrm{bbl} / \mathrm{d}$

$1330 \mathrm{bbl} / \mathrm{d}$

$38183 \mathrm{bbl} / \mathrm{d}$

$16132 \mathrm{bbl} / \mathrm{d}$

$2000 \mathrm{bbl} / \mathrm{d}$

$231036 \mathrm{bbl} / \mathrm{d}$

$(378,000) \mathrm{bbl} / \mathrm{d}$

$(146964) \mathrm{bbl} / \mathrm{d}$ 
The above calculation shows that the samples' total current refining capacity is less than the current consumption of the country. Therefore, when Pakistan cannot meet the current consumption with the current available refining capacities it cannot meet the future consumption too. So the higher we import oil the higher will be the import bill and affect on economy.

\section{Method 3.Crude Oil Reserves}

Pakistan's total crude oil reserves are $935 \mathrm{mbbl}$ out of which $609 \mathrm{mbbl}$ are already recovered. The remaining oil reserves are estimated at $326 \mathrm{mbbl}$. The average production is $69954 \mathrm{bbl} / \mathrm{d}$.

\section{Case 1}

Remaining reserves/Average Production $=326,000,000 /(69954) *(365)$

No. of years reserves lasts $=12.76$ years

The above calculation shows that Pakistan's reserve will last for 12.76 years if the current production remains stagnant till 2017. However, Pakistan imports crude oil to meet its oil needs standing at $350,000 \mathrm{bbl} / \mathrm{d}$ whereas the refining capacity is only $270,000 \mathrm{bbl} / \mathrm{d}$. Case 1 does not take into account the increasing demand of crude oil and shows a simplistic view of meeting oil needs

\section{Case 2}

Realizing the demand of crude oil in the country, GoP has decided to increase crude oil production to $100,000 \mathrm{bbl} / \mathrm{d}$ by 2010 . In this case

Remaining reserves $/$ Average Production $=326,000,000 /(100,000) *(365)$

No. of years reserves lasts $=8.9$ years.

Thus, all the three methods yield the same results i.e., it is not feasible for Pakistan to be self sufficient in meeting its oil demand by 2017 and it will have a negative impact on our economy. Therefore, null hypothesis is accepted and alternate hypothesis is rejected.

\section{SUMMARY OF FINDINGS}

\section{Macroeconomic Effects}

The magnitude of the direct effect of a given price increase depends on the share of the cost of oil in national income, the degree of dependence on imported oil and the ability of end-users to reduce their consumption and switch away from oil. Unless country is running in surplus, or has extremely large foreign exchange reserves, high oil price is dealt by a reduction in total demand for all imported goods, so as to restore balance of payments equilibrium. Higher oil prices leads to inflation, increased input costs, reduced non-oil demand and lower investment in net oil importing countries. Tax revenue falls and the budget deficit increases. It is the reduction in domestic demand (both consumption and investment) which leads to reduced imports and reduced domestic production. If real wages are sticky downwards this also results in increased unemployment.

\section{GDP Growth and Oil prices}

At the time oil prices have been rising, Pakistan's economy has shown a high growth trend (for the last five years) (Table 4) resulting in a substantial increase in the demand for energy. Theoretically, increasing oil prices squeeze income and demand. At a given exchange rate, more domestic output is needed to pay for the same volume of oil imports (Lardic, S. and R. Mignon (2006). If the domestic currency depreciates in response to induced payments deficits, this further cuts the purchasing power of domestic income over imported goods. Lower profits may then result in the decline in investment spending and cause potential output to fall over an expanded period. It is somehow difficult to identify the factors been responsible for the high growth in Pakistan in the presence of high oil prices. One reason might be consumers have been shielded by limiting the direct pass through to final oil prices. The extensive use of fuel subsidies in the form of PDC was helped by strong foreign reserves position; it may have contained output losses in the past few years. 
Table No. 4 GDP Growth in Percent

\begin{tabular}{|l|c|c|c|c|c|}
\hline & $\mathbf{2 0 0 3 - 0 4}$ & $\mathbf{2 0 0 4 - 0 5}$ & $\mathbf{2 0 0 5 - 0 6}$ & $\mathbf{2 0 0 6 - 0 7}$ & $\mathbf{2 0 0 7 - 0 8}$ \\
\hline GDP & 6.4 & 8.4 & 6.6 & 7 & 5.8 \\
\hline
\end{tabular}

In addition, the continued strong performance of the services sector had made contribution to the GDP outcome. On the demand side it is the consumption expenditure that has proved to be the main source of growth in GDP for the last couple of years, here credit flow to private sector in the form of consumer financing played a significant role. But since 2006-07 situation has somewhat started changing. Private sector consumed Rs. 23.533 billion from July 1st to Oct 20th, 2007against Rs. 69.870 billion in the corresponding period last year. Credit to small and medium enterprises is also on the decline given high interest rates and undocumented trade. With this scenario it would be difficult to maintain the high growth pattern.

\section{Oil Prices and Inflation}

Another channel via which high oil prices may affect macroeconomic performance is through the high costs of production thus reducing output. This supply side channel exerts an inflationary pressure on the economy (Lardic, S. and V. Mignon (2008). In addition, higher oil prices directly raise consumer prices via higher prices of imported goods and petroleum products in the consumption basket. When the rate of inflation is high, governments may be concerned with adding it further and hence less willing to see a full passing on of oil price increase. High oil prices has also become an important factor (along with rising house rents and shortage of food items) contributing to high inflation in Pakistan in the past few years. General Price level (for virtually all goods and assets) has been increasing (9.3 percent in 2004-05 considerably very high compared to the previous years). Even in the last two years average inflation was near 8 percent (Table 5). Despite efforts from SBP through tight monetary policy19 (high interest rates) average inflation was 7.1 percent in the first quarter of $2007 / 08$.

Table No. 5 Consumer Price Index Trend

\begin{tabular}{|l|r|r|r|r|}
\hline & \multicolumn{1}{|c|}{$\mathbf{2 0 0 4 - 0 5}$} & \multicolumn{1}{|c|}{$\mathbf{2 0 0 5 - 0 6}$} & \multicolumn{1}{|c|}{$\mathbf{2 0 0 6 - 0 7}$} & \multicolumn{1}{|c|}{$\mathbf{2 0 0 7 - 0 8}$} \\
\hline Average CPI Increase & $9.30 \%$ & $8.25 \%$ & $8 \%$ & $9.49 \%$ \\
\hline
\end{tabular}

\section{Balance of Payment Effect}

On Nov 30, OPEC members agreed to reduce output by 1.2 million barrels a day in the first production cuts by OPEC in over eight years. Non-OPEC members joined in on Dec 10, with Russia leading the way in cutting 300,000 barrels out of a total 528,000 barrels a day cut. Oil prices have sharply rebounded and crossed the $\$ 56$ a barrel mark following these agreements. Following the $1.8 \mathrm{~m}$ barrels a day cut, experts have updated their price forecasts and now expect the price of oil to hover closer to the $\$ 70$ a barrel in 2017.

Higher oil prices will increase Pakistan's import bill and increased petroleum prices will intensify inflationary pressures. The rupee, which is already under pressure, will face further depreciation in the market as Pakistan reckons with both a resurgent dollar and rising import bill. Under such a scenario the State Bank would have to dip into its foreign currency reserves to stabilize the rupee and pay for oil imports.

In the coming years Pakistan will also face rising external financing needs - these cannot be met by the current inflow of dollars from exports and remittances. According to IMF data, the country will require over \$13bn a year from 2017 to 2020 . This estimate does not take into account the depletion of foreign currency reserves that could occur under the scenario highlighted above. Given this reality, 
one can expect that Pakistan will struggle to meet its external financing needs and could find itself back in the arms of the IMF.

Our petroleum imports account for 24 percent of total imports (and represented up to 44 percent of export earnings) in 2006-07. While, in 1999-2000 the share of petroleum imports was 27 percent of total imports and accounts for 33 percent of total export earnings. Improving terms of trade would mean that a smaller volume of exports would be needed to pay for a given quantity of imports. Similarly, the percentage point growth in exports that would be needed to pay for a $75 \%$ rise in the cost of imported oil is potentially very large (i.e., $18 \%$ ). This estimate is for the $75 \%$ increase in oil prices but in actual the prices have risen more than $100 \%$. It means the required rate for exports growth is much higher than this. It was only in 2002-03, where exports growth has crossed $18 \%$. However, imports overall have grown quite significantly.

\section{CONCLUSION}

For long run development oil will remain an important source of energy. What is required is to make rational choices about the development of energy mix for the future. The government should chalk out strategies for ensuring efficiency in use and development, adequacy and reliability of supply, and measures to alleviate environmental impacts. For Investor's confidence in all energy sectors a predictable and transparent framework is essential. Since better investor climate will in turn increase supply and help stabilize prices. Within the framework of a national energy policy, a number of specific measures to promote energy efficiency and diversity will help in reducing vulnerability to high oil prices.

About $28 \%$ of total commercial energy is imported in Pakistan and the dependence on imported fuels is expected to increase even further in future given the depleting gas resources. The continuously rising trend in the oil prices in the international market will have a negative impact on Pakistan's foreign reserves.

\section{RECOMMENDATIONS}

Pakistan needs to explore the vast potential of its indigenous energy resources, much of which has remained unexploited, especially that of coal. The government must diversify the country's energy supply mix to reduce the risk of oil price fluctuations in the global energy market.

Energy conservation programs should be applied. There is a need to seriously promote efficiency improvement or demand management. So far this seems to be a lost opportunity for Pakistan. As discussed earlier, some countries have successfully implemented this approach. At the macro level, government policy cannot completely eliminate the adverse impacts of high oil prices but appropriate policy response can minimize it.

\section{REFERENCES}

Ahmed, A., and M. J. Kumar (2008) Status of Petroleum Sector in Pakistan- A Review. oil \& gas business.

Akram, M., (2012) Do crude oil price changes affect economic growth of India, Pakistan and Bangladesh?: A multivariate time series analysis. Hogskolan Dalarna D class thesis.

Chuku, A. C., E. L. Effiong and N. R. Sam (2010), "Oil Price Distortions and Their Short- and Long-Run Impacts on the Nigerian Economy", MPRA Paper No. 24434, Available at http://mpra.ub.uni-muenchen.de/24434/

Colongni, A. and M. Manera (2008), "Oil Prices, Inflation and Interest Rates in a structural Cointegrated VAR Model for the G-7 Countries”, Energy Economics, Vol. 30, pp. 856- 
888.

Abeysinghe, Tilak (2001) Estimation of Direct and Indirect Impact of Oil price on Growth, Economic Letters, Vol. 73, pp.147-153.

Cunado, J. and Perez de Gracia (2005) Oil Prices. Economic Activity and Inflation: Evidence forSome Asian Countries, The Quarterly Review of Economics and Finance, Vol. 45, pp. 65-83

Dohner, R.S. (1981), "Energy Prices, Economic Activity and Inflation: Survey of Issues and Results", in K.A Mork (eds), Energy Prices, Inflation and Economic Activity, Cambridge Mass: Ballinger.

Abid, M., and M. Sabri (2012) Energy Concept-Economic Growth Nexus: Does the Level of Aggregation Matter?. International Journal of Energy Economic and Policy. Vol.2, Pp.5562.

Gisser, M. and T. H. Goodwin (1986), "Crude Oil and the Macroeconomy: Tests of Some Popular Notions", Journal of Money Credit and Banking, Vol. 18, pp. 95-103.

Levent, K. (2007) Testing Causal Relationship between Energy Consumption, Real Income and Prices: Evidence from Turkey. MPRA Paper No.21834.

Jongwanich, J. and D. Park (2009), "Inflation in Developing Asia", Journal of Asian Economics, Vol. 20, pp. 507-518.

Kilian, L. (2010), "Oil Price Volatility: Origins and Effects", World Trade Organization Staff Working Paper No. ERSD-2010-02.

Langdon, D. Clough (2007), Energy Profile of Pakistan, Energy and Geography, Energy Information Administration, January 20, 2007, pp.1. (Pakistan Energy Yearbook (2008), Hydrocarbon Development Institute of Pakistan, Ministry of Petroleum and Natural Resources, Government of Pakistan.Oil and Gas Regulatory Authority (OGRA) (2008) Annual Report 2007-08. Oil and Gas Regulatory Authority, Islamabad, www.ogra.org.pk

Lardic, S. and R. Mignon (2006), "The Impact of Oil Price on GDP in European Countries: An Empirical Investigation Based on Asymmetric Cointegration”, Energy Policy, Vol. 34, pp. 3910-3915.

Lardic, S. and V. Mignon (2008), "Oil Prices and Economic Activity: An Asymmetric CointegrationApproach", Energy Economics, Vol. 30, pp. 847-855.

Muhammad. (2013). An econometrics Analysis of oil price Volatility. International Journal of economic and finance, pp1-4.

Muhammad. (2013). An econometrics Analysis of oil price Volatility. International Journal of economic and finance, pp1-4.

Nadia, I. A. (2013). The impact of Oil Prices on stock and CPI in the Pakistan. IOSR journal, pp43-57. 